\title{
Krisis Keuangan Masa Depan dan Sistem Keuangan Baru
}

\author{
Anggi Pratiwi Sitorus ${ }^{1 *}$, Mahlel $^{2}$, M. Shabri A. Majid ${ }^{3}$, \\ Marliyah $^{4}$, Rita Handayani ${ }^{5}$ \\ 1,4,5 Universitas Islam Negeri Sumatera Utara, Kabupaten Deli Serdang, Provinsi \\ Sumatera Utara, Indonesia. \\ ${ }^{2}$ Institut Agama Islam (IAI) Al-Aziziyah Samalanga Bireuen Aceh, Kabupaten \\ Bireuen, Provinsi Aceh, Indonesia. \\ ${ }^{3}$ Universitas Syiah Kuala, Kota Banda Aceh, Provinsi Aceh, Indonesia.
}

\begin{abstract}
Abstrak. Krisis keuangan pada dasarnya merupakan sebagai kondisi perekonomian mengalami penurunan dengan cepat yang disebabkan oleh permintaan uang yang melebibi penawaran uang karena terjadinya bank rush dalam jumlah yang besar. Dalam rangka mengupayakan pemantauan dan kajian terbadap stabilitas sistem perbankan dan sistem keuangan nasional yang lebih akurat guna mengbindari terulangnya systemic risk, dalam hal tugas pengawasan dan pembinaan bank. telah dipisabkan dari Bank Indonesia, maka Bank. Indonesia selaku bank sentral perlu diberi wewenang untuk dapat mengakses secara langsung data di sektor perbankan yang reliable. Penelitian menggunakan pendekatan kualitatif deskriptif dengan temuan penelitian bahwa dampak krisis terbadap perekonomian terbukti memberikan dampak yang buruk terbadap perekonomian Indonesia dan seperti yang telah dijelaskan babwa krisis ekonomi terutama krisis keuangan itu memiliki periode yang mengulang, artiny a apabila sebuah negara pernah terjangkiti sebuah krisis ekonomi maka tidak serta merta negara tersebut akan lepas dari krisis ekonomi, karena mungkin terjadi lagi. Dan stabilitas sistem kenangan merupakan suatu kondisi dimana mekanisme ekonomi dalam penetapan harga, alokasi dana dan pengelolaan risiko berfungsi secara baik. dan mendukung pertumbuhan ekonomi.
\end{abstract}

Kata kunci: Krisis Keuangan; Sistem Kenangan Baru.

Abstract. The financial crisis is basically a condition of the economy experiencing a rapid decline caused by the demand for money that exceeds the supply of money due to the occurrence of a large bank. rush. In order to seek more accurate monitoring and review of the stability of the banking system and national financial system in order to avoid the recurrence of systemic risk, in the event that the supervisory and supervisory duties of banks have been separated from Bank Indonesia, then Bank Indonesia as the central bank needs to be authorized to be able to directly access reliable data in the banking sector. The study uses a descriptive qualitative approach with research findings that the impact of the crisis on the economy has proven to have a bad impact on the Indonesian economy and as has been explained that the economic crisis, especially the financial crisis, has a repeating period, meaning that if a country has ever been affected by an economic crisis, it will not be affected by the economic crisis. the country will soon be free from the economic crisis because it might happen again. And financial system stability is a condition in which economic mechanisms in pricing, allocation of funds, and risk management function properly and support economic growth.

Keywords: Financial Crisis; New Financial System.

*Corresponding Author. Email: anggisitorus1@gmail.com 1*

DOI: https://doi.org/10.35870/emt.v6i1.561

Received: 11 January 2022, Revision: 6 February 2022, Accepted: 8 February 2022, Available Online: 13 February 2022. Print ISSN: 2579-7972; Online ISSN: 2549-6204.

Copyright@ 2022. Published by Lembaga Otonom Lembaga Informasi dan Riset Indonesia (KITA INFO dan RISET). 


\section{Pendahuluan}

Krisis keuangan global yang bermula dari krisis kredit perumahan di Amerika Serikat membawa implikasi pada kondisi ekonomi global secara menyeluruh. Hampir di setiap negara, baik di kawasan Amerika, Eropa, maupun Asia Pasifik, merasakan dampak akibat krisis keuangan global tersebut. Krisis ini berdampak pada ketidakpercayaan masyarakat pada sistem keuangan, dan sangat membahayakan sistem perbankan. Kalau sistem perbankan ambruk, ekonomi akan runtuh, rakyat akan sengsara. Mengingat, perkembangan di dunia perbankan yang sangat pesat serta tingkat kompleksitas yang tinggi dapat berpengaruh terhadap performa suatu bank. Kompleksitas usaha perbankan yang tinggi dapat meningkatkan resiko yang dihadapi oleh bank-bank yang ada di Indonesia. Permasalahan perbankan di Indonesia antara lain disebabkan oleh lemahnya kondisi internal bank, dan modal yang tidak dapat mengcover terhadap resiko-resiko yang dihadapi oleh bank tersebut menyebabkan kinerja bank menurut Ruslan Abdullah (2014)

Krisis keuangan yang terjadi di Indonesia, khususnya dikaitkan dengan liberalisasi perbankan yang berawal pada tahun 1988 yang merupakan salah satu faktor pemicu lemahnya sistem keuangan, khususnya perbankan. Terjadinya gejolak di pasar uang, pasar valas dan pasar modal serta meningkatnya ketidakpastian (uncertainty) dapat mengakibatkan semakin memburuknya adverse selection dan moral hazard yang pada gilirannya mengakibatkan runtuhnya kestabilan sektor keuangan. Untuk kasus Indonesia, gejolak nilai tukar negara-negara regional memiliki pengaruh paling utama yang menyebabkan terjadinya krisis yang berkepanjangan. Kuatnya tekanan terhadap rupiah mengakibatkan ketidakmampuan Bank Indonesia untuk menyangga pita intervensi (band intervention) yang ada sehingga sistem nilai tukar mengambang bebas (free floating system) menjadi salah satu alternatif sistem nilai tukar yang akhirnya dipilih untuk tetap menjaga cadangan devisa. Disamping sebagai dampak dari bergejolaknya nilai rupiah, sektor perbankan mengalami krisis yang sangat mendalam karena menurunnya kepercayaan masyarakat terhadap sistem perbankan. Hal tersebut semakin diperberat oleh lemahnya kondisi internal sektor perbankan, terutama sebagai dampak dari konsentrasi kredit yang berlebihan, lemahnya manajemen bank, moral bazard yang timbul akibat mekanisme exit yang belum tegas serta belum efektifnya peagawasan yang dilakukan oleh Bank Indonesia.

Krisis keuangan yang terjadi sejak 1997 mengancam kelangsungan hidup perusahaan. Kreditor (bondholder) dihadapkan pada dilema dalam menentukan kebangkrutan atau restrukturisasi perusahaan debitor. Studi prediksi kelangsungan hidup perusahaan menjadi persoalan yang menarik untuk dikaji kembali secara empiris. Apakah efek krisis keuangan lebih bersifat synchronous. Sequential juga menjadi persoalan yang menarik untuk mengkaji apakah perspektif keuangan yang menekankan pada data historis rasio keuangan masih relevan dalam menjelaskan dan memprediksikan kelangsungan hidup perusahaan pasca krisis keuangan 1997. Seberapa efektif manajer melakukan perubahan kebijakan stratejik perusahaan untuk melepaskan diri dari kesulitan keuangan juga masih belum memberikan hasil optimal (Agami, 2002).

Secara keseluruhan, akibat dari krisis yang semakin mendalam telah memperburuk tidak saja aspek likuiditas perbankan, tetapi juga aspek solvabilitas dan rentabilitasnya mengingat perbankan merupakan market dominan dalam industri keuangan di Indonesia, maka secara sistematis sektor Keuangan juga mengalami kelumpuhan. Krisis keuangan dan perbankan tersebut telah menyedot keuangan negara yang mencapai selatar 50\% dari PDB Indonesia, sehingga dapat dikategorikan terbesar dalam sejarah krisis keuangan. Biaya krisis tersebut tentu saja belum memperhitungkan dampak negatif krisis pada perekonomian secara keseluruhan akibat hilangnya perlu pertumbuhan ekonomi, investasi dan tingkat pengangguran, social cost lainnya akibat terjadinya instabilitas sosial politik sebagai dampak ikutan di saat krisis terjadi.

Persoalan-persoalan (issues) tersebut merupakan topik yang masih menarik dan menjadi perdebatan untuk dikaji lebih lanjut. Krisis keuangan pada dasarnya merupakan sebagai 
kondisi perekonomian mengalami penurunan dengan cepat yang disebabkan oleh permintaan uang yang melebihi penawaran uang karena terjadinya bank rush dalam jumlah yang besar. Kondisi tersebut terjadi karena hilangnya kepercayaan deposan terhadap bank yang seringkali disebabkan oleh guncangan di sektor pasar uang, kemudian memberikan efek buruk kepada stabilitas nilai tukar rupiah. Namun ada halnya krisis keuangan didefinisikan sebagai kondisis dimana EMP (exchange market pressure) sebuah negara melebihi nilai rata-ratanya di tambah satu standar deviasi. EMP sendiri diartikan sebagai variabel yang menjelaskan hubungan antara pergerakan nilai tukar dengan intervensi kebijakan pemerintah, sehingga melalui variabel ini dapat mengukur tingkat pengaruh intervensi kebijakan terhadap target nilai tukar yang diinginkan. Tujuan dari penelitian ini, antara lain untuk mengetahui indikator yang mempengaruhi besaran variabel makro ekonomi terbaik untuk meramalkan terjadinya krisis mata uang rupiah di Indonesia. Studi ini merupakan studi eksplorasi yaitu studi yang dilakukan karena terdapatnya sebuah fenomena atau masalah yang belum jelas penyelesaian ataupun penjelasannya, studi eksplorasi berusaha untuk menemukan metode yang paling baik untuk menyelesaikan masalah tersebut, termasuk metode pengumpulan data yang tepat dan merumuskan permasalahan dengan tepat.

\section{Tinjauan Literatur}

Secara umum, krisis ekonomi kontemporer terjadi karena satu atau kombinasi dari beberapa jenis krisis, seperti krisis perbankan, krisis nilai tukar, krisis utang pemerintah, krisis neraca pembayaran, krisis keuangan, krisis moneter, kejatuhan pasar saham, economy bubble, dan hiperinflasi. Krisis ekonomi dapat memicu atau dipicu oleh krisis sosial dan politik. Krisis ekonomi akan menyebabkan kontraksi ekonomi yang kemudian mengarah pada stagnasi, resesi, depresi, pengangguran, deprivasi, kelaparan, kematian, serta masalah dan ketidakstabilan ekonomi, sosial dan politik lainnya (Ascarya, 2009).

Krisis yang timbul akibat defisit keuangan negara akibat utang negara yang sangat besar berdampak pada krisis ekonomi di kawasan Eropa dan berdampak pada negara berkembang (Pshenichnov, 2020). Banyak ekonom mulai membuka wacana untuk mengkaji ulang sistem ekonomi yang ada karena tidak memberikan kesejahteraan bagi masyarakat (Bowles \& Gintis, 2012). Krisis ekonomi dunia dalam dekade terakhir, dan masih belum terselesaikan, menyebabkan resesi besar yang melibatkan semua sektor ekonomi utama (Marazziti et al., 2021; Eid Balbaa, 2020). Karena faktor ekonomi dapat mempengaruhi kesejahteraan mental, tidak mengherankan jika peningkatan kesehatan mental yang buruk diamati di berbagai negara, sementara merupakan tantangan besar untuk intervensi psikiatri (Guillén, 2020; Semieniuk et al., 2021). Untuk memastikan keamanan dan kesehatan sistem keuangan global serta lembaga keuangan individu dan untuk mengurangi risiko sistemik (Monasterolo, 2020), berbagai langkah kebijakan dan reformasi peraturan telah diajukan sebagai reaksi terhadap Krisis keuangan global dan krisis utang negara. Tinjauan holistik dan sistematis memungkinkan untuk mengekstrak rekomendasi dan bidang tindakan yang relevan untuk mencegah krisis semacam itu di masa depan (Ranjbari et al., 2021; Meherali et al., 2021; Yuen et al., 2020).

\section{Metodologi Penelitian}

Penelitian menggunakan pendekatan kualitatif deskriptif, yang mana penelitian deskriptif tidak dimaksudkan untuk menguji hipotesis tertentu, tetapi hanya menggambarkan "apa adanya" tentang sesuatu variabel, gejala, atau keadaan (Arikunto, 2003).Sedangkan Moleong mendefinisikan penelitian kualitatif adalah penelitian yang bermaksud untuk memahami fenomena tentang apa yang dialami oleh subjek penelitian misalnya perilaku, persepsi, motivasi, tindakan dan lain-lain secara holistik dan dengan cara mendeskripsikan berbentuk kata maupun bahasa yang baik pada suatu konteks khusus secara alamiah serta memanfaatkan berbagai metode alamiah (Moleong, 2017).

Metode yang digunakan adalah kepustakaan (library research), yaitu mengumpulkan data atau karya tulis ilmiah yang berkaitan dengan obyek penelitian atau pengumulan data yang bersifat 
kepustakaan. Atau telaah yang dilaksanakan untuk memecahkan suatu masalah yang pada dasarnya tertumpu pada penelaahan kritis dan mendalam terhadap bahan- bahan pustaka yang relevan. Studi kepustakaan adalah teknik pengumpulan data dengan mengadakan studi penelaahan terhadap buku-buku, literaturliteratur, catatan-catatan dan laporan-laporan yang ada hubungannya dengan masalah yang dipecahkan (Nazir, 2012)

\section{Hasil dan Pembahasan}

\section{Krisis Keuangan Berikutnya Dan Sistem Keuangan Baru}

Krisis keuangan dapat terjadi dalam berbagai kondisi di mana beberapa lembaga atau aset keuangan kehilangan sebagian besar nilai-nilai mereka. Peristiwa krisis tersebut dapat terjadi dalam bentuk kesulitan keuangan (financial distress), krisis kepanikan perbankan atau krisis perbankan sistemik, jatuhnya pasar saham, meledaknya penggelembungan keuangan (financial bubble), jatuhnya mata uang, kesulitan neraca pembayaran, kegagalan pelunasan utang pemerintah, atau kombinasi dari dua peristiwa atau lebih. Krisis yang paling sering terjadi adalah berbagai jenis krisis keuangan, seperti krisis perbankan, krisis nilai tukar, dan krisis utang pemerintah. Teori yang mendasari krisis keuangan telah banyak dibahas dalam literatur ekonomi konvensional, namun belum banyak dibahas dalam literatur ekonomi Islam. Sub bab berikutnya akan membahas teori krisis keuangan berdasarkan perspektif konvensional dan ekonomi Islam.

Jenis krisis keuangan dalam literatur ekonomi konvensional termasuk krisis mata uang atau krisis neraca pembayaran/BOP, krisis perbankan, krisis utang pemerintah, dan jatuhnya pasar saham/aset. Pada kenyataannya, krisis keuangan di sebuah negara terdiri dari dua atau lebih jenis yang terjadi secara bersamaan atau secara berturut-turutKrisis mata uang atau Krisis BOP Krisis mata uang atau krisis BOP terjadi ketika nilai mata uang terdepresiasi dengan cepat sehingga melemahkan kemampuannya untuk berfungsi sebagai alat tukar atau penyimpan nilai, karena kelebihan permintaan mata uang asing (biasanya dalam Dolar AS atau Euro) yang tidak dapat dipenuhi oleh cadangan devisa negara. Jika negara mengadopsi rezim kurs tetap, pemerintah dipaksa untuk mendevaluasi mata uangnya dan/atau mengadopsi rezim kurs mengambang. Para pembeli mata uang asing biasanya adalah para investor asing yang mencoba mengungsikan aset atau modal mereka ke tempat yang aman, yang menjadikan neraca pembayaran negara beroperasi dalam keadaaan yang benar-benar defisit. Contoh krisis mata uang adalah krisis Peso pada tahun 1994 di Meksiko, krisis keuangan Asia (Thailand, Malaysia, Indonesia dan Korea) pada tahun 1997, krisis keuangan Rusia pada tahun 1998, dan krisis keuangan di Brazil dan Argentina pada tahun 1999.

Kemudian adapun krisis keuangan yang terjadi secara luas mengakibatkan gangguan di pasar keuangan sehingga menimbulkan kendala terhadap aliran kredit untuk keluarga, bisnis yang menimbulkan efek buruk terhadap sektor riil dan jasa. Istilah ini lazim digunakan untuk para investor secara tibatiba kehilangan sejumlah investasinya dan lembaga keuangan tiba-tiba kehilangan proporsi yang signifikan dari nilai investasi para investor. Krisis keuangan dapat terjadi dalam beberapa sekmen pasar, yaitu: crash pasar saham, bable ekonomi, krisis mata uang dan defaults nilai tukar. Gelembung (bubble) ekonomi umumnya terjadi karena kemudahan dalam memberikan kredit rumah tangga, hutang yang berlebihan, spekulasi, keserakahan, penipuan, dan korupsi. Kemudahan dalam memberikan kredit menyebabkan hilangnya disiplin dalam nilai pasar yang memadai, pada akhirnya terjadi intigates pinjaman dengan kebijakan yang tidak bijaksana. Penciptaan hutang dalam sistem keuangan Islam harus didukung oleh barang dan jasa. Instrumen hutang tidak mudah untuk diperdagangkan kecuali dibarengi oleh barang dan jasa tertentu untuk menghindari atau berjaga-jaga apabila terjadi fluktuasi.

Barang dan jasa merupakan hal yang fleksibel dalam sistem moneter Islam. Oleh karena itu, efek spekulasi akan mendestabilisasi pembatasan secara signifikan. Sistem moneter dalam model keuangan Islam berkaitan langsung dengan komuditas dan jasa. Dengan kata lain, dikotomi antara aktivitas keuangan 
berjalan secara riil, keuangan secara langsung dialokasikan untuk keperluan tertentu terhadap barang dan jasa. Dari beberapa kajian para ahli, penyebab utama krisis keuangan disebabkan oleh kelemahan standar pinjaman yang diadopsi oleh lembagan keuangan termasuk juga perbankan yang didorong oleh keserakahan dengan tujuan untuk mendapatkan keuntungan yang tinggi, dan juga kurangnya control oleh pemerintah sesuai dengan ketentuan yang memadai. Hal ini juga dipicu oleh pemberian kredit untuk usaha kecil dengan pendapatan masyarakat terendah, diperburuknya lagi karena perbankan tidak melakukan selektif dengan cermat bagi pemohon kredit dengan kriteriakriteria yang sesuai dengan adat masyarakat setempat dalam kerangka pengembangan ekonomi.

Krisis keuangan telah terbukti secara nyata bahwa kekuatan dari pasar uang modern sebagai cikal-bakal kapitalisme adalah sebuah ilusi. Mood bappy-go-luck bable seketika karena kenaikan dan inflasi mendorong harga naik secara global seketika tanpa bisa dikontrol oleh pemerintah. Krisis keuangan yang terjadi menimbulkan pemikiran ulang terhadap industry perbankan. Hal ini menyebabkan untuk meninjau kembali sistem kapitalisme dalam penataan sistem keuangan yang mendukung penciptaan uang dan uang. Penciptaan uang merupakan model dalam menyuntikan modal sehingga memicu masalah besar di dunia perbankan.

Dampak krisis terhadap perekonomian terbukti memberikan dampak yang buruk terhadap perekonomian Indonesia dan seperti yang telah dijelaskan bahwa krisis ekonomi terutama krisis keuangan itu memiliki periode yang mengulang, artinya apabila sebuah negara pernah terjangkiti sebuah krisis ekonomi maka tidak serta merta negara tersebut akan lepas dari krisis ekonomi, karena mungkin terjadi lagi. Besar kemungkinannya sebuah negara mengalami krisis berkali-kali dengan sebuah periode yang setiap negara mempunyai cirinya masingmasing. Mengetahui bahwa krisis ekonomi mempunyai pola yang berulang maka beberapa peneliti ekonomi (ekonom) membuat sebuah kajian yang memungkin untuk bisa meramalkan kemungkinan terjadinya krisis ekonomi.
Melakukan pemilihan variabel fundamental makro ekonomi indonesia menggunakan metode Leading Indicator dalam menjelaskan terjadinya krisis ekonomi dijelaskan sebagai berikut:

1. Composite leading indicator, merupakan konsep yang paling cocok untuk memilihvariabel yang akan digunakan untuk meramalkan krisis di Indonesia,

2. Real misalignment rupiah adalah penyebab krisis ekonomi di Indonesia.

Ketika adanya krisis pemerintah sebaiknya berhati-hati terhadap hutang luar negeri yang masih memiliki porsi yang besar terhadap GDP dan pemerintah juga sebaiknya memperhatikan Contagion effect yang mempengaruhi stabilitas mata uang rupiah. Konsep umum dari metode peramalan untuk krisis ekonomi ini adalah dengan melakukan pendefinisian krisis (periode terjadinya krisis) dengan memonitoring pergerakan EMP (Exchange Market Pressure), EMP banyak digunakan karena mampu memberikan gambaran periode krisis yang tepat, kemudian EMP tersebut akan dijadikan variabel dependen. Pendekatan yang dilakukan adalah dengan mencari variabel independen yang akan dijadikan indikator peramalan tersebut. Variabel yang dipilih dapat juga diambil dari berbagai macam kategori, namun berdasarkan analisa yang peneliti lakukan berdasarkan penelitian terdahulu, sebagian besar variabel yang akan dijadikan indikator merupakan variabel yang diambil dari rasionalitas ekonomi karena variabel tersebut mempengaruhi besaran variabel fundamental makro ekonomi. hal ini disebabkan variabel fundamental makro ekonomi mempunyai beberapa kelebihan yaitu,

1. Karena variabel fundamental makro ekonomi adalah variabel dasar yang memperlihatkan stabilitas perekonomian sebuah negara

2. Berdasarkan teori penjalaran krisis (contagion), krisis terjadi pertama kali di sektor keuangan yang kemudian merambat melalui jalur perdagangan internasional (Trade) sehingga merambat lebih jauh ke nilai mata uang dan neraca pembayaran kemudian mulai mendorong terjadinya inflasi. 
Kemudian setelah itu krisis mulai masuk ke sektor riil melalui perbankan. Variabel yang mempengaruhi besaran variabel fundamental makro ekonomi ini akan dijadikan variabel independen terhadap EMP Krisis bisa diramalkan melalui monitoring variabel independen yang memiliki tingkat penjelasan (explanation) yang baik terhadap krisis (melalui EMP), apabila krisis bisa diramalkan maka pemerintah akan mempunyai kesempatan untuk menerapkan kebijakan yang lebih terencana dan tepat untuk menghadapi krisis ekonomi tersebut. Kebijakan pemerintah maupun bank sentral yang diterapkan saat krisis berlangsung memberikan kecenderungan bahwa kebijakan pemerintah yang diambil terkadang sudah terlambat, sedangkan masalah harus segera diselesaikan. Hal ini menyebabkan krisis ekonomi yang sedang berjalan akan mempunyai masa perbaikan yang lebih lama dan terkadang pula malah membuat krisis ekonomi semakin dalam.

Kebijakan yang dapat dilakukan dan sebaiknya difokuskan dalam mengantisipasi terjadinya krisis adalah kebijakan moneter karena argumentasi berikut ini:

1. Fenomena krisis ekonomi banyak melibatkan variabel moneter pada shock awalnya (baru setelah itu variabel yang terkait dengan kebijakan fiskal dan kebijakan lainnya)

2. Kebijakan moneter mampu memberikan pengaruh yang lebih baik dalam mengontrol EMP (variabel paling penting dalam membaca gerakan krisis ekonomi. Oleh karena itu yang perlu ditekankan adalah evaluasi terhadap kebijakan moneter dalam penanganan krisis yang telah berlangsung selama ini agar mendapatkan rekomendasi untuk strategi yang lebih baik.

Berdasarkan dari sisi perusahaan, perusahaan dengan tingkat related diversification yang lebih tinggi cenderung menghambat potensi untuk mengalami kondisi zombie saat krisis keuangan global terjadi. Hasil penelitian mendukung theory of the growth of the firm yang menyatakan bahwa ekspansi bisnis adalah usaha untuk meningkatkan kinerja dan menjamin kemampuan bersaing jangka panjang. Pada konteks perusahaan berorientasi domestik dan internasional, hasil penelitian menunjukkan bahwa diversifikasi adalah faktor yang penting, dengan pengaruh yang lebih tinggi pada perusahaan dengan orientasi domestik. Implikasi hasil penelitian bagi regulator adalah lebih mempermudah pengembangan bisnis terutama pada bisnis terkait atau related. Untuk penelitian selanjutnya, pertama adalah memperluas ruang lingkup penelitian pada kondisi non-krisis atau ketika krisis lain terjadi seperti krisis industri. Kedua dapat menggunakan definisi rombie yang lebih restriktif yaitu perusahaan yang berkesinambungan mendapatkan subsidi kredit dari pihak ketiga. Hal ini sangat diperlukan karena penelitian di Indonesia dengan topik ini masih sangat terbatas serta memungkinkan memberikan kontribusi pada teori zombie yang masih pada tahap awal pengembangan.

\section{Menjaga Stabilitas Sistem Keuangan}

Sistem keuangan memegang peranan yang sangat penting dalam perekonomian seiring dengan fungsinya untuk menyalurkan dana dari pihak yang berkelebihan dana kepada pihakpihak yang membutuhkan dana. Apabila sistem keuangan tidak bekerja dengan baik, maka perekonomian menjadi tidak efisien dan pertumbuhan ekonomi yang diharapkan tidak akan tercapai. Salah satu masalah krusial dalam sistem keuangan yang dapat menjadi sumber instabilitas keuangan yakni menyangkut terjadinya asimetri/ketidaksamaan informasi (asymmetric information) yakni suatu situasi dimana satu pihak yang terlibat dalam kesepakatan keuangan tidak memiliki informasi yang akurat dibanding pihak lain. sebagai contoh, peminjam (debitur) biasanya memiliki informasi yang lebih baik keuntungan dan kerugian potensial dari suatu proyek. investasi yang direncanakan dibandingkan dengan pihak pemberi pinjaman (kreditur).

Dengan demikian, kreditur tidak dapat membedakan antara pinjaman yang sehat dan tidak sehat. Permasalahan asimetri informasi selanjutnya menyebabkan dua permasalahan pokok yakni adverse selection dan moral hazard. Adverse selection merupakan satu bentuk masalah asimetri, informasi yang terjadi sebelum transaksi keuangan dilakukan karena peminjam 
dengan kualitas yang rendah (memiliki resiko kredit tinggi) biasanya akan mau mencari pinjaman dengan bunga yang sangat tinggi. Dari masalah adverse selection inilah sebagian besar dari pinjamannya biasanya merupakan Kredit bermasalah. Asimetri informasi ini juga menggambarkan dampak lanjutan dari krisis finansial pada perekonomian misalnya dalam kondisi suku bunga naik, mungkin berakibat pada adverse selection sehingga mengakibatkan penurunan penawaran kredit oleh bank. Demikian pula kondisi penurunan nilai agunan yang menyebabkan timbulnya debitur dengan net worth yang rendah. Akhirnya bila terjadi bank runs, bank yang sehat dapat memproteksi dirinya dengan mencadangkan lebih banyak likuiditas yang berakibat kontraksi dari sisi pemberian kreditnya.

Dalam rangka mengupayakan pemantauan dan kajian terbadap stabilitas sistem perbankan dan sistem keuangan nasional yang lebih akurat guna menghindari terulangnya systemic risk, dalam hal tugas pengawasan dan pembinaan bank telah dipisahkan dari Bank Indonesia, maka Bank Indonesia selaku bank sentral perlu diberi wewenang untuk dapat mengakses secara langsung data di sektor perbankan yang reliable. Selain itu, keselarasan kebijakan dan peraturan antara sektor moneter, sistem pembayaran, perbankan dan kebijakan dan peraturan di sektor fiskal dan sektor riil perlu untuk dikembangkan agar stabilitas sistem perbankan dan sistem keuangan nasional dapat terpelihara. Untuk mencapai kondisi itu, dengan dibentuknya otoritas baru di sektor perbankan, yaitu OJK dan LPS, maka diperlukan pula tersedianya perangkat hukum yang secara formal mengatur tegas dan jelas mengenai mekanisme koordinasi antar lembaga terkait dengan stabilitas sistem keuangan nasional, yaitu Bank Indonesia, OJK, LPS, dan DepKeu. Disamping itu, operasionalisasi perangkat hukum yang merupakan produk dari masingmasing otoritas itu harus ditegakkan (law enforcement), sehingga kepatuhan (complaince) terhadap aturan-aturan tersebut diharapkan akan mendorong terciptanya tata kerja perusahaan yang baik (good corporate governance) yang pada akhirnya mendukung berfungsinya market discipline.
Proses penyempurnaan dari sistem keuangan perbankan setidaknya perlu untuk ditinjau embali, empat hal penting yang perlu diperhatikan pembuat peraturan dalam proses merancang perangkat hukum, yaitu bahwa kiranya perlu yaitu: Pertama menjauhkan konflik kepentingan ekonomi politik jangka pendek dalam menyusun peraturan. Kedua mewaspadai keteledoran dalam perumusan detail dalam rangka mengantisipasi dampak negatif kebijakan yang dipilih. Ketiga melakukan sinkronisasi dengan peraturan terkait; dan Keempat menghindarkan diri dari ketergesagesaan hanya karena harus memenuhi target waktu, karena hal itu hanya akan berakibat pada pembahasan substansi secara dangkal dan tidak matang.

Kemudian pada tataran kebijakan, Indonesia menggunakan dua indikator pengukuran stabilitas sistem keuangan yakni mikroprudensial dan makroprudensial. Indikator mikroprudensial diantaranya adalah: rasio kecukupan modal perbankan, kualitas aset, manajemen sistem keuangan yang sehat, pendapatan dan keuntungan bank, aspek likuiditas, sensitivitas terhadap risiko pasar dan beberapa indikator berbasis pasar. Sementara itu, indikator makroprudensial diantaranya: pertumbuhan ekonomi, balance of payment, tingkat inflasi, suku bunga dan nilai tukar, contagion effect atau efek menular krisis, serta faktor-faktor lain. Stabilitas sistem keuangan didasarkan pada tingkat kesehatan institusi keuangan dan kestabilan kondisi pasar keuangan. Ukuran tingkat kesehatan institusi keuangan yang dimaksudkan adalah bagaimana suatu institusi keuangan dapat melaksanakan fungsi intermediasi atau fungsi jasa keuangan lainnya, seperti seistem pembayaran dengan baik dan lancar. Stabilitas pasar keuangan merupakan kemampuan pasar untuk melakukan jual beli aset dengan harga yang mendekati nilai fundamentalnya.

Pelaku sistem keuangan tidak hanya meliputi bank sentral, bank komersial, asuransi, lembaga sekuritas, namun juga institusi lain yang secara langsung dan tidak langsung juga berkaitan dengan intitusi keuangan seperti rumah tangga, institusi non finansial, pemerintah, sektor publik, pasar finansial dan properti. Bank 
Indonesia memiliki peranan penting dalam menjaga stabilitas sistem keuangan (SSK) melalui kebijakan makroprudensial guna mencegah terjadinya risiko sistemik. Kebijakan tersebut tertuang dalam Peraturan Bank Indonesia No. 16/11/PBI/ 2014 tentang Pengaturan dan Pengawasan Makroprudensial yang menyebutkan bahwa dalam menjalankan pengaturan makroprudensial, Bank Indonesia menggunakan sejumlah instrumen salah satunya melalui fungsi intermediasi, serta mengendalikan berbagai risiko seperti risiko kredit, risiko likuiditas, risiko nilai tukar, risiko suku bunga, serta risiko lain yang memungkinkan munculnya risiko sistemik.

Bank Indonesia sebagai bank sentral memiliki lima peranan utama dalam menjaga stabilitas sistem keuangan. Kelima peranan utama yang mencakup kebijakan dan instrumen dalam menjaga stabilitas sistem dapat dijelaskan sebagai berikut:

1. Bank Indonesia memiliki tugas untuk menjaga stabilitas moneter antara lain melalui instrumen suku bunga dalam operasi pasar terbuka. Bank Indonesia dituntut untuk mampu menetapkan kebijakan moneter secara tepat dan berimbang. Hal ini mengingat gangguan stabilitas moneter memiliki dampak langsung terhadap berbagai aspek ekonomi. Kebijakan moneter melalui penerapan suku bunga yang terlalu ketat, akan cenderung bersifat mematikan kegiatan ekonomi atau sebaliknya. Oleh karena itu, untuk menciptakan stabilitas moneter, Bank Indonesia telah menerapkan suatu kebijakan yang disebut inflation targeting framework.

2. Bank Indonesia memiliki peran vital dalam menciptakan kinerja lembaga keuangan yang sehat, khususnya perbankan. Penciptaan kinerja lembaga perbankan seperti itu dilakukan melalui mekanisme pengawasan dan regulasi. Seperti halnya di negara-negara lain, sektor perbankan memiliki pangsa yang dominan dalam sistem keuangan. Oleh sebab itu, kegagalan di sektor ini dapat menimbulkan ketidakstabilan keuangan dan meng - ganggu perekonomian. Untuk mencegah terjadinya kegagalan tersebut, sistem pengawasan dan kebijakan perbankan yang efektif haruslah ditegakkan. Selain itu, disiplin pasar melalui kewenangan dalam pengawasan dan pembuat kebijakan serta penegakan hukum (law enforcement) harus dijalankan. Bukti yang ada menunjukkan bahwa negara-negara yang menerapkan disiplin pasar, memiliki stabilitas sistem keuangan yang kokoh. Sementara itu, upaya penegakan hukum (law enforcement) dimaksudkan untuk melindungi perbankan dan stakeholder serta sekaligus mendorong kepercayaan terhadap sistem keuangan. Untuk menciptakan stabilitas di sektor perbankan secara berkelanjutan, Bank Indonesia telah menyusun arsitektur perbankan indonesia dan rencana implementasi Basel II.

3. Bank Indonesia memiliki kewenangan untuk mengatur dan menjaga kelancaran sistem pembayaran. Bila terjadi gagal bayar (failure to settle) pada salah satu peserta dalam sistem sistem pembayaran, maka akan timbul risiko potensial yang cukup serius dan mengganggu kelancaran sistem pembayaran. Kegagalan tersebut dapat menimbulkan risiko yang bersifat menular (contagion risk) sehingga menimbulkan gangguan yang bersifat sistemik. Bank Indonesia mengembangkan mekanisme dan pengaturan untuk mengurangi risiko dalam sistem pembayaran yang cenderung semakin meningkat. Antara lain dengan menerapkan sistem pembayaran yang bersifat real time atau dikenal dengan nama sistem RTGS (Real Time Gross Settlement) yang dapat lebih meningkatkan keamanan dan kecepatan sistem pembayaran. Sebagai otoritas dalam sistem pembayaran, Bank Indonesia memiliki informasi dan keahlian untuk mengidentifikasi risiko potensial dalam sistem pembayaran.

4. Melalui fungsinya dalam riset dan pemantauan, Bank Indonesia dapat mengakses informasi-informasi yang dinilai mengancam stabilitas keuangan. Melalui pemantauan secara macroprudential, Bank Indonesia dapat memonitor kerentanan sektor keuangan dan mendeteksi potensi kejutan (potential shock) yang berdampak pada stabilitas sistem keuangan. Melalui riset, Bank Indonesia dapat mengembangkan instrumen dan indikator macroprudential untuk mendeteksi kerentanan sektor 
keuangan. Hasil riset dan pemantauan tersebut, selanjutnya akan menjadi rekomendasi bagi otoritas terkait dalam mengambil langkah-langkah yang tepat untuk meredam gangguan dalam sektor keuangan.

5. Bank Indonesia memiliki fungsi sebagai jaring pengaman sistim keuangan melalui fungsi bank sentral sebagai lender of the last resort (LoLR). Fungsi LoLR merupakan peran tradisional Bank Indonesia sebagai bank sentral dalam mengelola krisis guna menghindari terjadinya ketidakstabilan sistem keuangan. Fungsi sebagai LoLR mencakup penyediaan likuiditas pada kondisi normal maupun krisis. Fungsi ini hanya diberikan kepada bank yang menghadapi masalah likuiditas dan berpotensi memicu terjadinya krisis yang bersifat sistemik. Pada kondisi normal, fungsi LoLR dapat diterapkan pada bank yang mengalami kesulitan likuiditas temporer namun masih memiliki kemampuan untuk membayar kembali. Dalam menjalankan fungsinya sebagai LoLR, Bank Indonesia harus menghindari terjadinya moral hazard. Oleh karena itu, pertimbangan risiko sistemik dan persyaratan yang ketat harus diterapkan dalam penyediaan likuiditas tersebut.

Kestabilan sistem keuangan merupakan syarat dalam mewujudkan stabilitas kebijakan moneter. Bank Indonesia mengimplementasikan kebijakan moneter melalui berbagai instrumen kebijakan moneter seperti jumlah uang beredar dan tingkat bunga guna mewujudkan stabilitas kebijakan moneter yang stabil. Agar pelaksanaan implementasi dari instrumen-instrumen tersebut tepat sasaran, maka dibutuhkan jalur kebijakan moneter yaitu Inflation Targeting Framework (ITF). Jadi, sistem keuangan yang stabil dapat dimaknai dengan kemampuan dalam mengalokasikan sumber dana serta meminimalisir terjadinya shock yang dapat mengganggu kegiatan sektor riil dan sistem. Berbeda halnya dengan ketidakstabilan sistem keuangan yang dapat diakibatkan berbagai macam gejolak seperti kegagalan pasar baik yang bersumber dari internal maupun eksternal.
Dapat disimpulkan bahwa stabilitas sistem keuangan adalah suatu kondisi dimana mekanisme ekonomi dalam penetapan harga, alokasi dana dan pengelolaan risiko berfungsi secara baik dan mendukung pertumbuhan ekonomi. Dan stabilitas sistem keuangan dapat dipahami dengan melakukan penelitian terhadap faktor-faktor yang dapat menyebabkan instabilitas di sektor keuangan. Ketidakstabilan sistem keuangan dapat dipicu oleh berbagai macam penyebab dan gejolak. Hal ini umumnya merupakan kombinasi antara kegagalan pasar, baik karena faktor struktural maupun perilaku. Kegagalan pasar itu sendiri dapat bersumber dari eksternal (internasional) dan internal (domestik). Risiko yang sering menyertai kegiatan dalam sistem keuangan antara lain risiko kredit, risiko likuiditas, risiko pasar dan risiko operasional.

Meningkatnya kecenderungan globalisasi sektor finansial yang didukung oleh perkembangan teknologi menyebabkan sistem keuangan menjadi semakin terintegrasi tanpa jeda waktu dan batas wilayah. Selain itu, inovasi produk keuangan semakin dinamis dan beragam dengan kompleksitas yang semakin tinggi. Berbagai perkembangan tersebut selain dapat mengakibatkan sumber-sumber pemicu ketidakstabilan sistem keuangan meningkat dan semakin beragam, juga dapat mengakibatkan semakin sulitnya mengatasi ketidakstabilan tersebut. Identifikasi terhadap sumber ketidakstabilan sistem keuangan umumnya lebih bersifat forward looking (melihat kedepan). Hal ini dimaksudkan untuk mengetahui potensi risiko yang akan timbul serta akan mempengaruhi kondisi sistem keuangan mendatang. Atas dasar hasil identifikasi tersebut selanjutnya dilakukan analisis sampai seberapa jauh risiko berpotensi menjadi semakin membahayakan, meluas dan bersifat sistemik sehingga mampu melumpuhkan perekonomian.

\section{Kesimpulan}

Penyelesaian krisis keuangan sangat mahal, menyakitkan dan komplek. Namun, krisis itu juga membawa pelajaran yang berharga. Berbeda dengan negara-negara Asia Timur lainnya, krisis ganda mata uang dan perbankan di Indonesia menimbulkan krisis politik, yang 
membuat penanganan krisis keuangan lebih sulit. Gejolak sosial dan politik membatasi alternatif kebijakan bagi para pengambil kebijakan saat itu. Tidak komprehensifnya strategi baik di tingkat mikro maupun tingkat makro, kurangnya komitmen menempuh kebijakan yang tegas serta tingginya intervensi politik mengakibatkan penyelesaian krisis kurang yang kurang efektif dan biaya fiskal yang lebih mahal. Agar efektif, proses penyelesaian krisis harus dilakukan secara obyektif, transparan, dan konsisten dalam rangka memulihkan kesehatan keuangan dan perekonomian. Dan dalam memahami krisis keuangan tidak hanya dilihat dari tingkat pertumbuhan eksporimpor melainkan harus dilihat perkembangan ekonomi dari sisi sistem perbankan, investasi maupun kebijakan moneter. Fenomena krisis hutang yang tidak bisa di bayar dan defisit serta kondisi ekonomi makro yang tidak menentu, terjadi akibat dari kebablasan hutang yang tak terbayarkan.

\section{Daftar Pustaka}

Abdullah, M. R. (2014). Determinan Profitabilitas Perbankan Syariah di Indonesia Pasca Krisis Keuangan Global. MUAMALAH, 4(2), 83-90.

Agami, Abdel M. (2002), "The Role That Foreign Acquisition of Asian Companies Played In The Recovery of The Asian Financial Crisis", Multinational Business Review, Spring, pp. 11- 20.

Ascarya, A. (2009). Pelajaran yang Dipetik dari Krisis Keuangan Berulang: Perspektif Ekonomi Islam. Buletin Ekonomi Moneter Dan Perbankan, 12(1), 33-82.

Bank Indonesia. 2007. Booklet Stabilitas Sistem Keuangan. Jakarta: Direktorat Penelitan dan Pengaturan Perbankan

Barus, J. H., \& Ramli, R. (2013). Analisis peramalan ekspor Indonesia pasca krisis keuangan eropa dan Global tahun 2008 dengan metode dekomposisi. Jurnal Ekonomi dan Keuangan, 1(3), 14880.
Bowles, S., \& Gintis, H. (2012). Democracy and capitalism: Property, community, and the contradictions of modern social thought. Routledge.

Eid Balbaa, M. (2020). The Predicted 2020 Global Economic Crisis: Causes and Prospects. The Light of Islam, 2020(2), 182192.

Fauziah, Ayu, F., \& Hidayatin, N. N. (2020). Inklusi Keuangan dan Stabilitas Sistem Keuangan (Bank Z-Score) di Asia. Optimal: Journal Ekonomi Dan Kewirausabaan, 14(1), 30-47.

Guillén, A. (2020). Coronavirus crisis or a new stage of the global crisis of capitalism?. Agrarian South: Journal of Political Economy, 9(3), 356-367.

Gunadi, I., Taruna, A. A., \& Harun, C. A. (2013). Penggunaan Indeks Stabilitas Sistem Keuangan (ISSK) dalam Pelaksanaan Surveilans Makroprudensial. Working Paper Bank Indonesia, 1-55.

Marazziti, D., Avella, M. T., Mucci, N., Della Vecchia, A., Ivaldi, T., Palermo, S., \& Mucci, F. (2021). Impact of economic crisis on mental health: a 10-year challenge. CNS spectrums, 26(1), 7-13.

Meherali, S., Punjani, N., Louie-Poon, S., Abdul Rahim, K., Das, J. K., Salam, R. A., \& Lassi, Z. S. (2021). Mental health of children and adolescents amidst COVID19 and past pandemics: a rapid systematic review. International journal of environmental research and public health, 18(7), 3432.

Moleong, Lexy J (2017). Metodologi Penelitian Kualitatif, Bandung: PT Remaja Rosdakarya.

Monasterolo, I. (2020). Climate change and the financial system. Annual Review of Resource Economics, 12, 299-320.

Muhammad Nazir (2012). Metode Penelitian, Jakarta: Ghalia Indonesia. 
Novita, S., Tjahjadi, B., \& Irwanto, A. (2019). Zombie Dan Diversifikasi Dalam Masa Krisis Keuangan Global. Jurnal Reviu Akuntansi dan Keuangan, 9(3), 295-308.

Pshenichnov, N. (2020). Islamic Economy as an Alternative Solution Economy Crysis. International Journal of Science and Society, 2(3), 285-294.

Ranjbari, M., Esfandabadi, Z. S., Zanetti, M. C., Scagnelli, S. D., Siebers, P. O., Aghbashlo, M., ... \& Tabatabaei, M. (2021). Three pillars of sustainability in the wake of COVID-19: A systematic review and future research agenda for sustainable development. Journal of Cleaner Production, 297, 126660.

Rusydiana, A. S., Rani, L. N., \& Hasib, F. F. (2019). Manakah Indikator Terpenting Stabilitas Sistem Keuangan?: Perspektif Makroprudensial. Jurnal Ekonomi dan Pembangunan, 27(1), 25-42.

Santoso, B., Muhajir, M. H., Hafidz, J., \& Surjaningsih, N. (2018). Analisis FaktorFaktor yang Mempengaruhi Perilaku Risk Taking Perbankan di Indonesia. Monograf Riset Stabilitas Sistem Keuangan, 21-27.

Sari, D. I. (2015). Analisis terhadap Peranan dan Strategi Bank Indonesia serta Pemerintah dalam Menjaga Stabilitas Sistem Keuangan di Indonesia. MoneterJurnal Akuntansi dan Keuangan, 2(1).
Semieniuk, G., Taylor, L., Rezai, A., \& Foley, D. K. (2021). Plausible energy demand patterns in a growing global economy with climate policy. Nature Climate Change, 11(4), 313-318.

Suharsimi Arikunto, (2003). Manajemen Penelitian, Jakarta: PT Rineka Cipta.

Wati, E. S. C., Rotinsulu, T. O., \& Siwu, H. F. D. . (2019). Analisis Faktor-Faktor Yang Mempengaruhi Stabilitas Sistem Keuangan di Indonesia Periode 2013:Q1 - 2018:Q4. Jurnal Berkala Ilmiah Efisiensi, 19(03), 149-159.

Wiku, F., \& Ayuningtyas, F. J. (2021). Determinan Stabilitas Sistem Keuangan Di Indonesia Melalui Pendekatan Makroekonomi. Tirtayasa Ekonomika, 16(2), 214-237.

Yuen, K. F., Wang, X., Ma, F., \& Li, K. X. (2020). The psychological causes of panic buying following a health crisis. International journal of environmental research and public health, 17(10), 3513.

Zulhilmi, M. (2017). Krisis Keuangan Eurozone: Studi Ekonomi dan Perbankan Islam. Media Syari'ab: Wabana Kajian Hukum Islam dan Pranata Sosial, 15(2), 191202. 